\title{
Assessment of the Trophic Status by Monitoring of Reservoir's Water Quality
}

\author{
Milka M. Vidović1 ${ }^{*}$, Marko N. Rodić ${ }^{2}$, Marija U. Vidović́ ${ }^{3}$, Ivana S. Trajković1, \\ Sanja Z. Jovanić ${ }^{1}$ \\ ${ }^{1}$ Department for Ecology and Technoeconomics, The Institute of Chemistry, Technology and Metallurgy, \\ University of Belgrade, Belgrade, Serbia \\ ${ }^{2}$ Faculty of Geography, University of Belgrade, Belgrade, Serbia \\ ${ }^{3}$ School of Electrical Engineering, University of Belgrade, Belgrade, Serbia \\ Email: ${ }^{*}$ mivibgd@yahoo.com
}

Received 18 December 2014; accepted 31 December 2014; published 14 January 2015

Copyright $@ 2015$ by authors and Scientific Research Publishing Inc.

This work is licensed under the Creative Commons Attribution International License (CC BY). http://creativecommons.org/licenses/by/4.0/

cc) (i) Open Access

\begin{abstract}
Continuous long-term monitoring of aquatic systems is important for understanding their complete evolution in order to monitor changes in the trophic status and water quality. The continuous monitoring during a period of 20 years, by sampling once a month at two locations, the water quality of reservoir "Grlište", which is used for the water supplying town Zaječar (Eastern Serbia), is observed and developmental stages in the life of the reservoir were determinated. It should be noted that the obtained results were used also in the purpose of finding a cause of cyanobacteria bloom, as a consequence of algal production. Limiting factors of algal production usually were nitrogen and phosphorus, however, in this study, obtained results of subtraction between trophic state index, calculated through total chlorophyll a (TSI (hl-a) $_{\text {) }}$ and trophic state index, calculated through total phosphorus ( $\mathrm{TSI}_{\mathrm{TP}}$ ), indicated that limiting factor of algal production was light. On the basis of the concentrations of dissolved oxygen (DO), total phosphorus (TP) and chlorophyll $a$ (Chl-a) in the surface and in the bottom, it was concluded that the reservoir passed through four development phases during the examined period. Results of long-term monitoring showed that in the first years after the formation of the reservoir, the highest trophicity was detected (hypereutrophic status), but later the reservoir mostly maintained eutrophic status.
\end{abstract}

\section{Keywords}

Monitoring, Reservoir, Trophic State Index, Eutrophication, Cyanobacteria

\footnotetext{
${ }^{*}$ Corresponding author.
} 


\section{Introduction}

Negative anthropogenic influences, supported by an increase in temperature, due to global climate changes affect the increase in total organic production and the level of saprobity, which directly reflects on the occurrence and dynamics of their trophicity [1] [2]. In most cases, reservoir is considered as a physical object, from hydroconstructional and hydrogeological aspect, and its geographical position and ecological-biological aspect are being neglected.

Filling phase of reservoir is characterized by low water quality and reduced transparency, which occur due to rising of suspended particles and inundation of soil [3] [4]. After the filling phase, the transparency of water in the reservoir increases, and after this period, the trend of decreasing water transparency is an indicator of the progressed eutrophication [5]. This kind of occurrence can be linked to an exuberant development of macrophytes, which contributed to higher transparency of water in the reservoir [3] [6]. In fact, macrophytes "clean the water" by reducing the amount of suspended particles and TP in the water column [7]. Also, the values of Chl-a concentrations, parameter which indicates the biomass of phytoplankton, are the highest after formation of the reservoir, which is in compliance to the theory of the reservoir's aging [3] [4] [8]. It is confirmed that the biomass of phytoplankton in fresh water lakes on certain occasions can be limited by light [9] [10]. Increased load of sediments and water with nutrients from tributaries, can largely affect the appearance of eutrophication and cause negative ecological effects on the recipients in the form of algal bloom and reduction of DO [11]-[14].

However, during the aging of reservoir, due to the increase in temperature of water at the bottom, the reduction conditions occurred, which caused the elution of phosphorus and ammonia in the water column [13] [15] [16]. The undesirable changes that may occur in water systems can be perceived on the basis of long-term monitoring of nitrate contents [13]. In addition to the usual parameters that characterize water quality of reservoirs, dynamics of trophicity can be estimated on the basis of the values of the parameters: Chl-a, transparency, as well as trophic state index of Carlson (TSI) [17]-[20]. Regardless of the increasing dynamics of trophicity, due to the impact of global climate change, long-term water supply programs are based on the building of large number of reservoirs.

By program of long term water supply of the Republic of Serbia, building of a larger number of reservoirs is planned for the needs of water supply and energetics as well. So far, in the Republic of Serbia more than 150 reservoirs have been built. In larger number of reservoirs, an accelerated process of eutrophication was detected, but small number of studies dealing with long term dynamics of reservoir trophicity was published. Reservoir "Grlište" is among more significant reservoirs on the territory of the Republic of Serbia and it is examined on several occasions [21].

Reservoir "Grlište" was built in 1989 by constructing a dam on the Grliška River for water supplying the town Zaječar and surrounding settlements (Eastern Serbia). Natural and anthropogenic influences give it the characteristics of an unstable aquatic system, in which eutrophication processes dominate. Eutrophication process of reservoir Grlište is becoming more actual, after frequent water blooms, significant amounts of cyanotoxins and consumers complaints about the smell of drinking water. This kind of problems required the identification of the cause which leads to degradation of water quality in the reservoir and factors which have long term effect on its trophicity.

\section{Materials and Methods}

Reservoir "Grlište" is located at 187 m above sea level, between mountain Tupižnica in the southwest and ravine of Zaječar in the northeast, upstream from the mouth of the Grliška river in Beli Timok (Eastern Serbia), which is shown on Figure 1. It stretches in the range of $28.5 \mathrm{~km}$ covering the area of 250 ha. Average water depth in the reservoir is $6 \mathrm{~m}$, and maximum depth is $22 \mathrm{~m}$ at a point just before the dam (place of water intake). Maximum volume of water in the reservoir is $12,000,000 \mathrm{~m}^{3}$, and average time of water retention in the reservoir is about 82 days. Reservoir receives water from a hilly basin, area of about $178 \mathrm{~km}^{2}$, and two tributaries which supply the reservoir are the Lenovačka river and Lasovačka river. Basin is located in the area with distinctive continental climate, with average annual amount of precipitation for the basin of $666.4 \mathrm{~mm}$. Area of basin reservoir can be considered as an agricultural region and it is threatened by erosive processes. Over time reservoir has become polyfunctional, even though its main purpose in the phase of projecting, building and filling was water supplying.

According to the plan and program of water quality management, in the period of 1991 to 2010, once a month, 


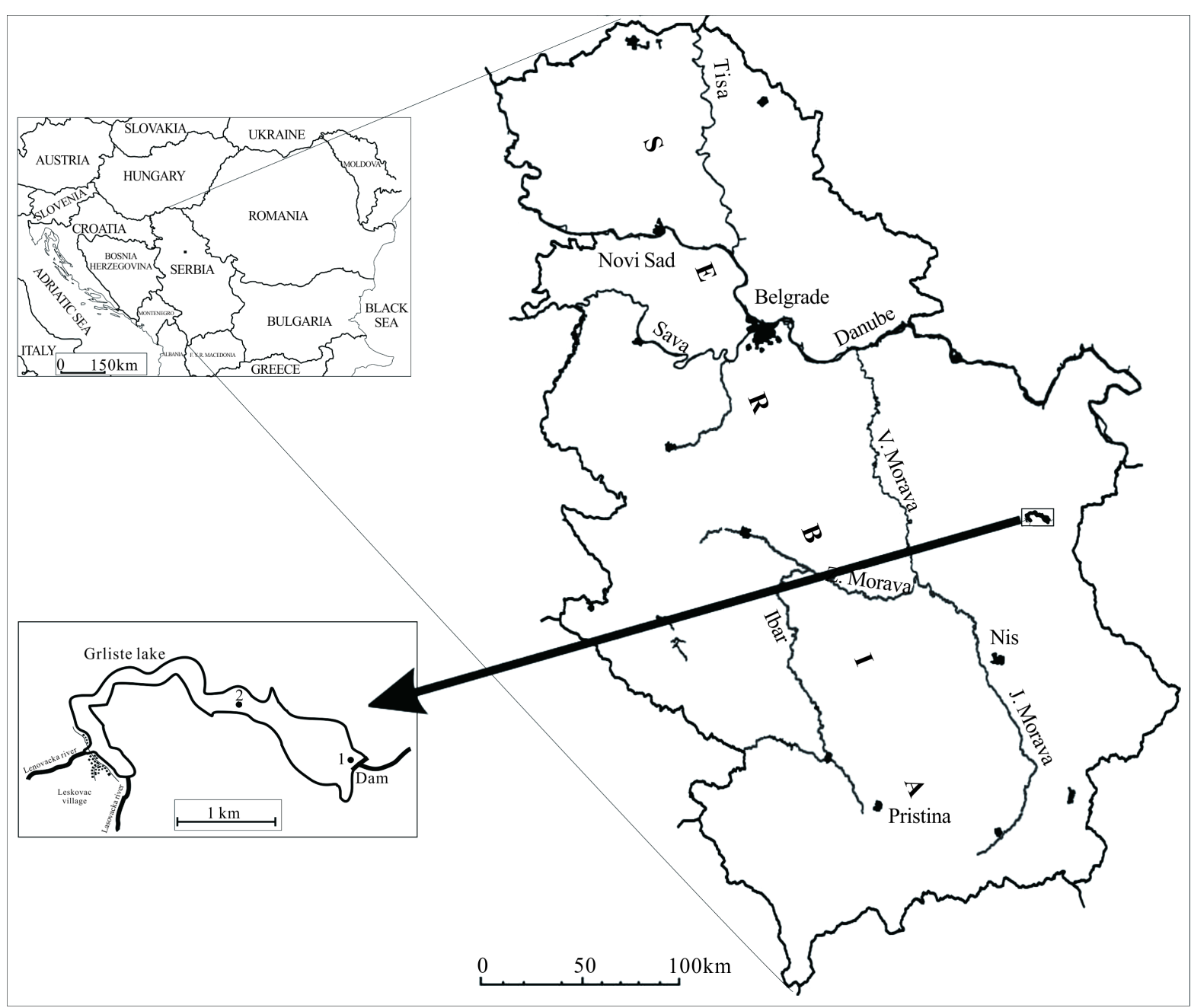

Figure 1. Reservoir Grlište with sampling point.

sampling of water was conducted from the reservoir Grlište. In the reservoir, sampling was conducted by a vertical profile at the middle of the reservoir at point 2 and at point 1 at the place of water intake (Figure 1). At both places, the sampling was conducted by the height of a water column at the surface $(0 \mathrm{~m}), 3 \mathrm{~m}, 5 \mathrm{~m}$ and 10 $\mathrm{m}$ depth and also at the bottom. At a sampling location, the temperature measurement was conducted, as well as $\mathrm{pH}$ value of water and transparency, using Secchi disc [22]. Samples for chemical analysis of water were collected in plastic bottles volume of $1 \mathrm{~L}$. In laboratory conditions, TP [23], and Chl-a, after filtering and acetone extraction [24] were determined spectrophotometrically on the spectrophotometer (Perkin Elmer, $\lambda 25 / 35 / 45$ UV Vis). Ammonia nitrogen $\left(\mathrm{NH}_{4}-\mathrm{N} \mathrm{L}^{-1}\right)$ were determined using ion chromatography [25]. Content of DO was determined by iodinemetric method [26].

The trophic state index of Carlson [27] was calculated on the basis of the values of water transparency measured by Secchi disc $\left(\mathrm{TSI}_{\mathrm{SD}}\right)$, surface values of Chl-a $\left(\mathrm{TSI}_{\mathrm{Chl}-\mathrm{a}}\right)$ and total phosphorus (TSI $\mathrm{TP}_{\mathrm{P}}$ ), according to Equations (1-3). Values of trophic state index of Carlson were considered in the range from 0 (ultra-oligotrophic status) to 100 (hypereutrophic status).

$$
\begin{aligned}
& \mathrm{TSI}_{\mathrm{TP}}=14.42 \cdot \ln \left(\mathrm{TP}_{\text {average }}\right)+4.15 \\
& \mathrm{TSI}_{\text {Chla }}=9.81 \cdot \ln \left(\text { Chla }_{\text {average }}\right)+30.6 \\
& \mathrm{TSI}_{\mathrm{TP}}=60-14.41 \cdot \ln \left(\mathrm{SD}_{\text {average }}\right)
\end{aligned}
$$


where:

$\mathrm{TP}_{\text {average }}$-is the average value of TP in the water column $\left(\mu \mathrm{g} \cdot \mathrm{L}^{-1}\right)$;

Chl-a $a_{\text {average }}$ - is the average value of Chl-a in the water column $\left(\mu \mathrm{g} \cdot \mathrm{L}^{-1}\right)$;

$\mathrm{SD}_{\text {average }}$ - is the water transparency measured by Secchi Disc (m).

In the period from April to October (during the vegetation season) throughout the examined period in the duration of 20 years, the obtained values of the examined parameters were statistically processed using basic indicators of descriptive statistics (arithmetic mean, median, minimum and maximum) using statistical program (STATISTICS 10.0).

\section{Results and Discussion}

Continuous long-term monitoring of water systems is significant for perception of their complete evolution, as well as for solving eventual problems, in relation to water quality. Importance of this study is that much greater, because the changes of chemical parameters and Chl-a were monitored by vertical and horizontal profile. Long-term dynamics of trophicity of the reservoir is perceived in adequate way, given that the monitoring included long enough period, from the filling of reservoir, until the end of the the examined period, 2010.

The lowest average values for water transparency $(1.1 \mathrm{~m})$ were after the reservoir filling, due to the rising of suspended particles due to the inundation of soil. Commonly, the transparency of the water in the reservoir decreases in time, however, in this study, the value of the water transparency in the reservoir Grlište was not decreasing, but, on the contrary, it was getting higher. The increasing trend of transparency is noticed at both points, during the entire examined period, which is shown on Figure 2 for point 1 and point 2 . This kind of occurrence is linked to an exuberant development of macrophytes [6] which contributed to higher transparency of water in the reservoir. In fact, macrophytes "clean the water" by reducing the amount of suspended particles and $\mathrm{TP}$ in the water column.

Low concentrations of oxygen in water in the first months after filling the reservoir can be explained by oxygen consumption, due to oxidation of organic matter which entered the water after the inundation. This occurrence is more distinct at point 1 where it lasted longer, because of insufficient mixing of surface water with the

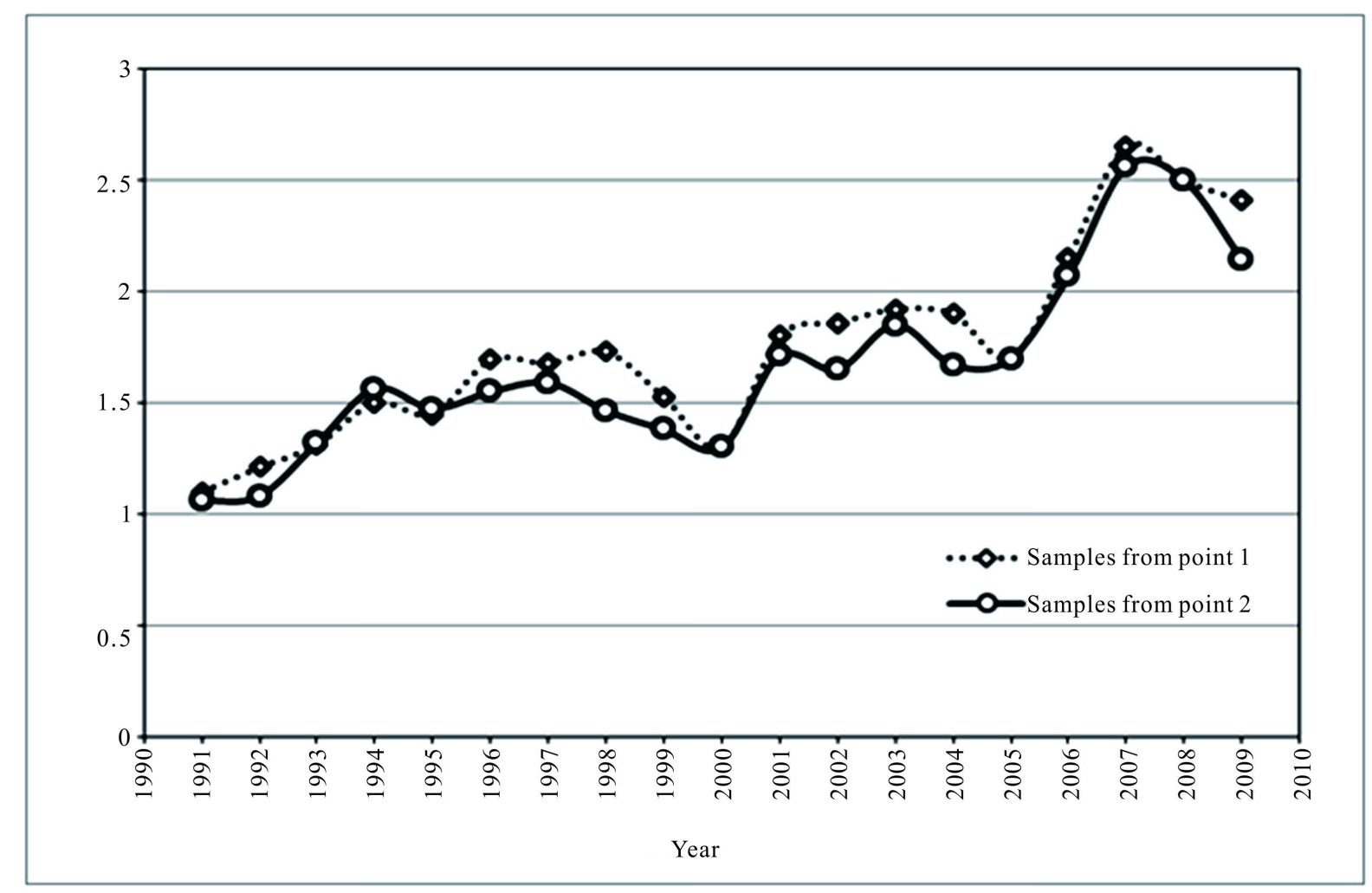

Figure 2. Average annual values of water transparency at point 1 and 2. 
water from the bottom, due to larger depth, where water depth reaches $20 \mathrm{~m}$. After the reservoir formation, concentrations of DO at the surface initially decreased, then increased, and by the end of the examined period remained approximately at the same level. The exception in this period is the year 2006, in which average values at the surface were slightly higher (more than $18 \mathrm{mg} \mathrm{O}_{2} \mathrm{~L}^{-1}$ ). Average annual values of the concentration of dissolved oxygen up to $3 \mathrm{~m}$ depth showed similar movement dynamics at sampling places at point 1 (Figure 3(a)) and at point 2 (Figure 3(b)). In the area of hypolimnion, especially at the bottom, differences between

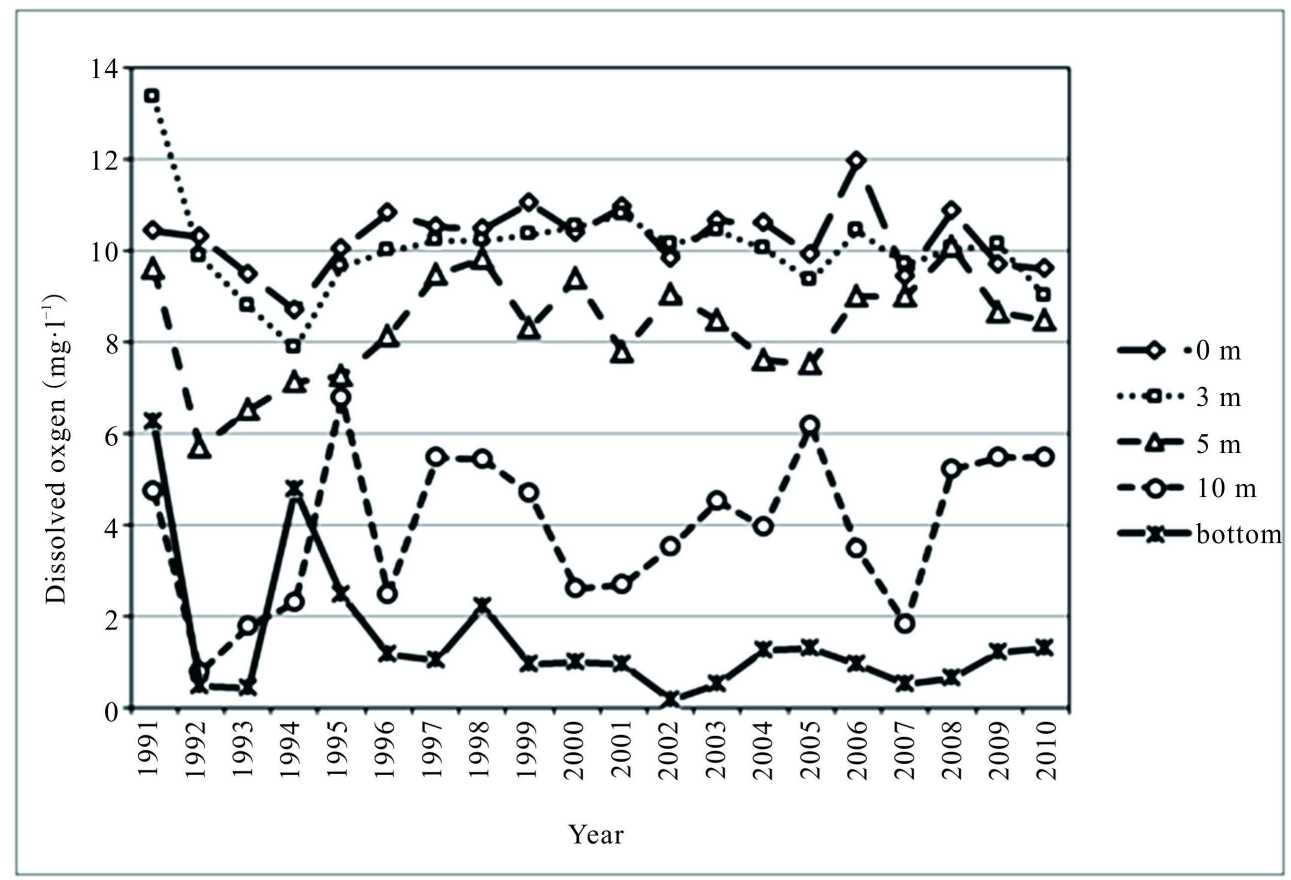

(a)

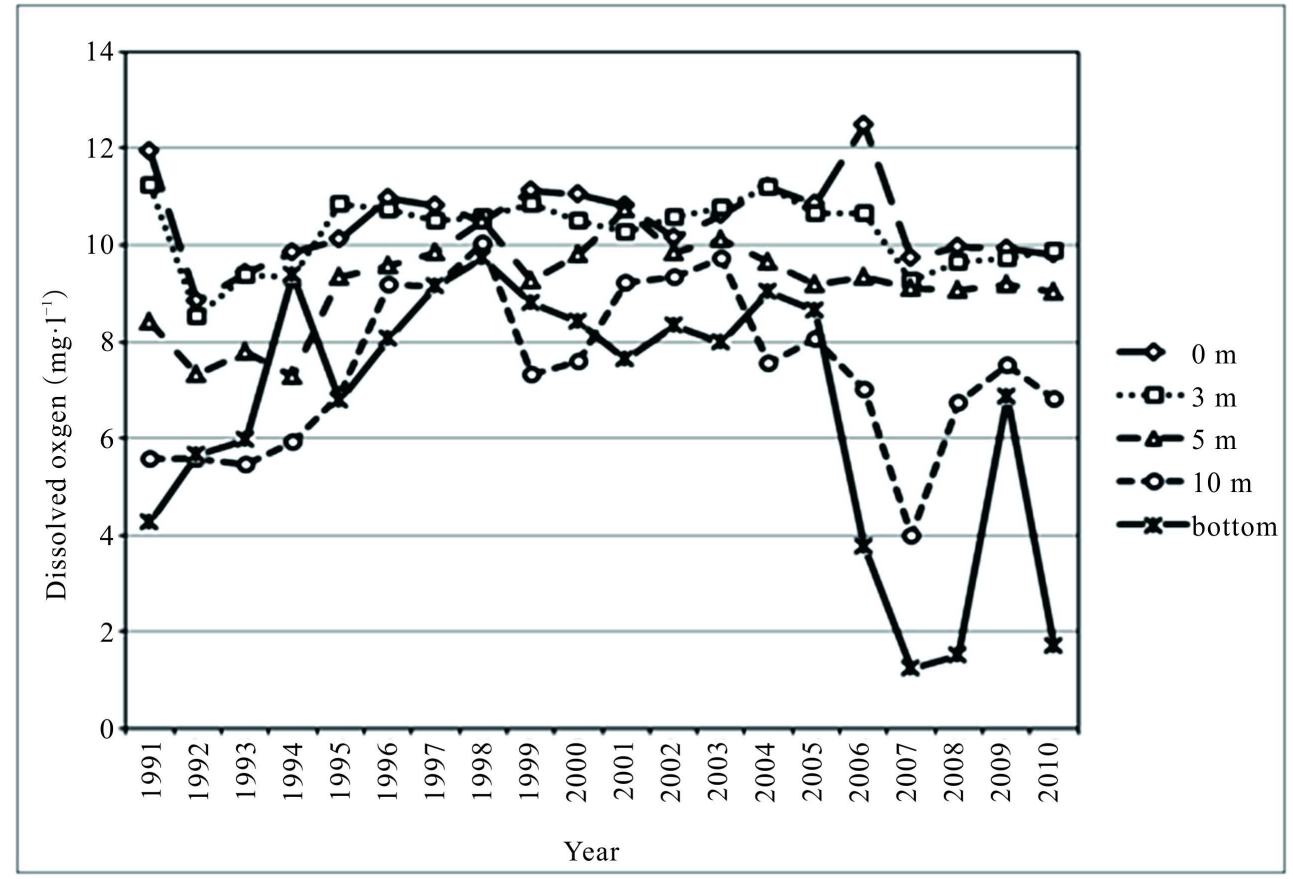

(b)

Figure 3. Average annual values of DO concentrations in water at (a) Point 1; (b) Point 2. 
these two points at a longitudinal profile of the reservoir were far more distinct. At point 1 , value of oxygen concentration (with the exception for the year 1991 and 1994 when it was $4 \mathrm{mg} \cdot \mathrm{L}^{-1}$ ), was below $2 \mathrm{mg} \cdot \mathrm{L}^{-1}$, and in 2002 total absence of oxygen was registered in the period from July to October. At point 2, the oxygen concentrations at the bottom, in the first three years since the formation of the reservoir, were slightly below 6 $\mathrm{mg} \cdot \mathrm{L}^{-1}$, and then until 2006 it was in the range from 6 to $10 \mathrm{mg} \cdot \mathrm{L}^{-1}$. Until the end of the examined period, at this point average concentrations of oxygen below $2 \mathrm{mg} \cdot \mathrm{L}^{-1}$ were registered. This can be explained by a massive development of phytoplankton, which causes the hypersaturation of surface layers with oxygen, while the death of algae leads to oxidation of deposited organic matter and reduction of values of oxygen concentration at the bottom. This process was continuing during 2007 and in 2008, when the water level in the reservoir was dropping.

The highest values of TP, at the bottom and at the surface, were registered in the first years after the reservoir filling, while later, only in certain years they reached high values (during the year 2001 at the bottom at point 2 and in the years 2002, 2003 and 2008 at the bottom at point 1). At point 1 (Figure 4(a)), significant oscillations were detected, up to three times higher average values of TP at the bottom, compared to point 2 (Figure 4(b)).

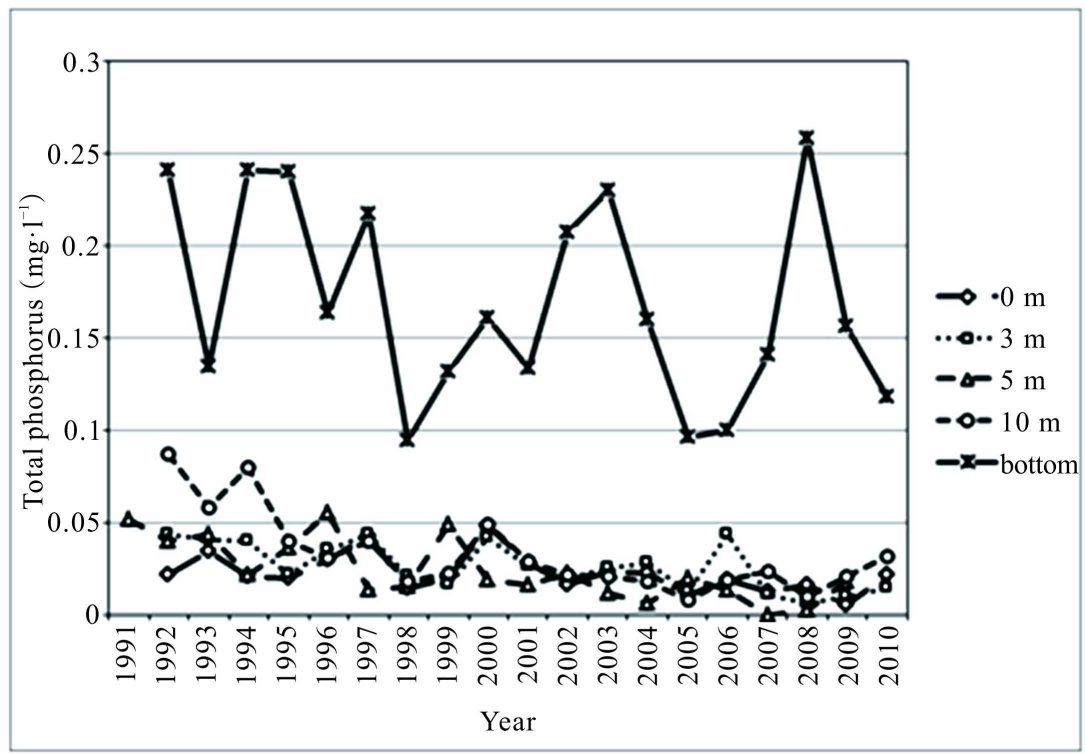

(a)

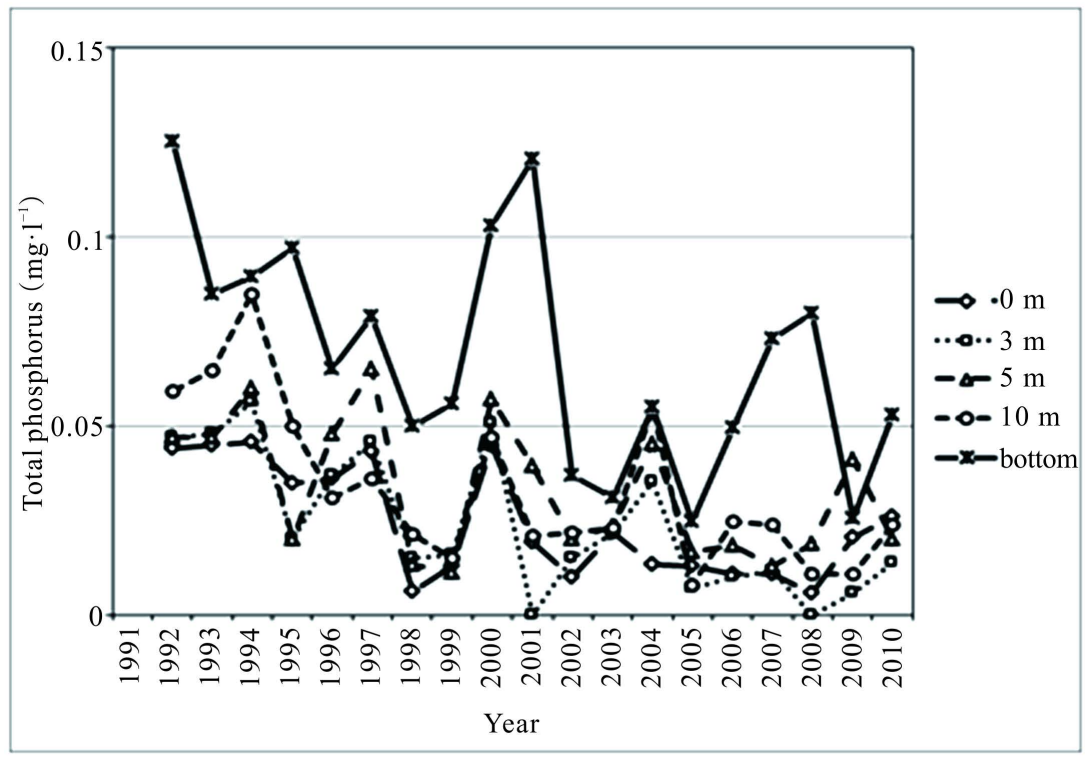

(b)

Figure 4. Average annual values of TP concentrations in water at (a) Point 1; (b) Point 2. 
Simultaneously, with the increase in content of phosphorus, content of ammonia had also risen, due to the creation of reduction conditions at the bottom, which was very distinctive at larger depths (point 1). Average annual concentrations of ammonia nitrogen had been increasing from the surface to the bottom at both analyzed locations in the reservoir. Concentrations of ammonia nitrogen nearby sediments showed twice higher values at point 1, compared to point 2 (Figure 5(a) and Figure 5(b)). This occurrence was confirmed by the absence of oxygen at the bottom in the period of several months at point 1, which can be seen from Figure 3(a).

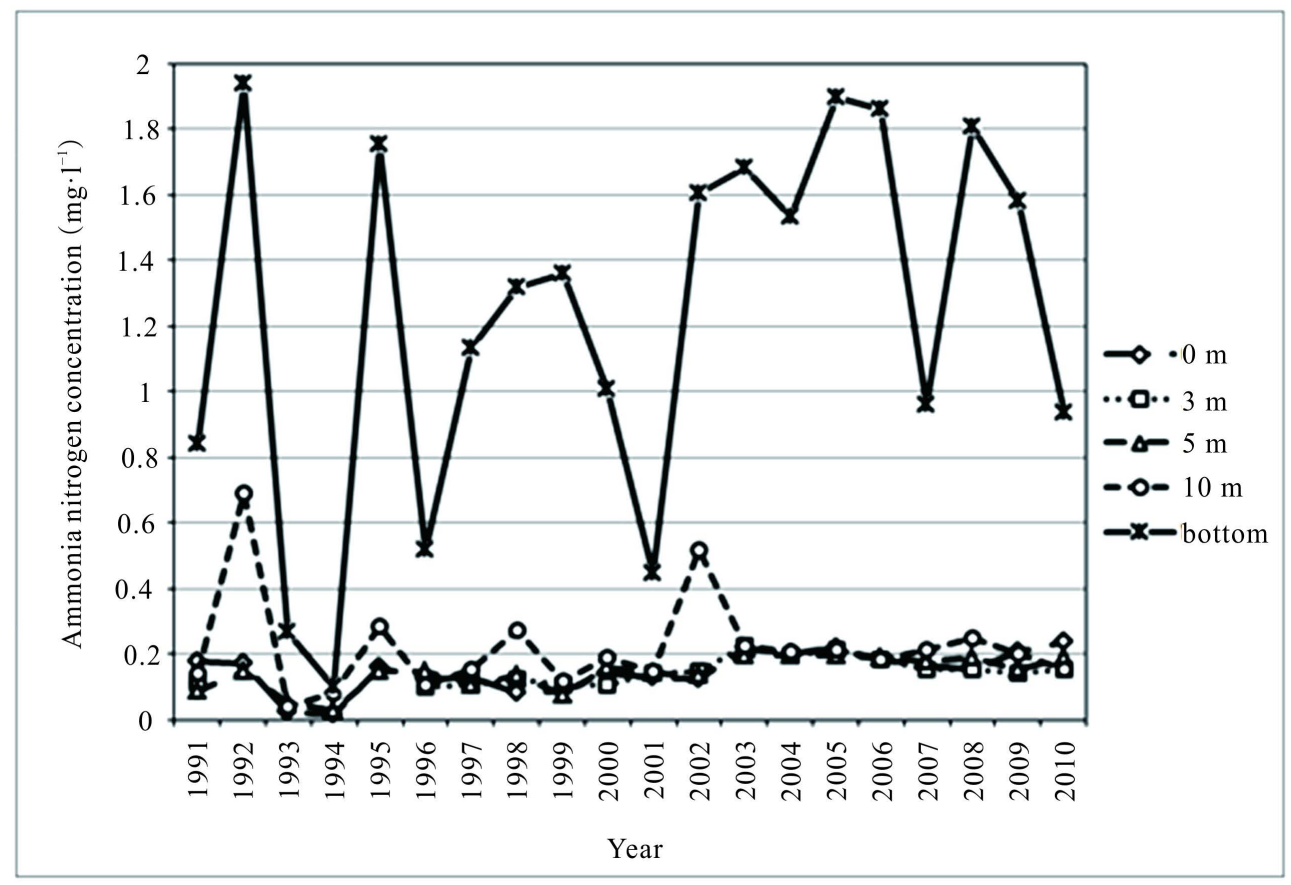

(a)

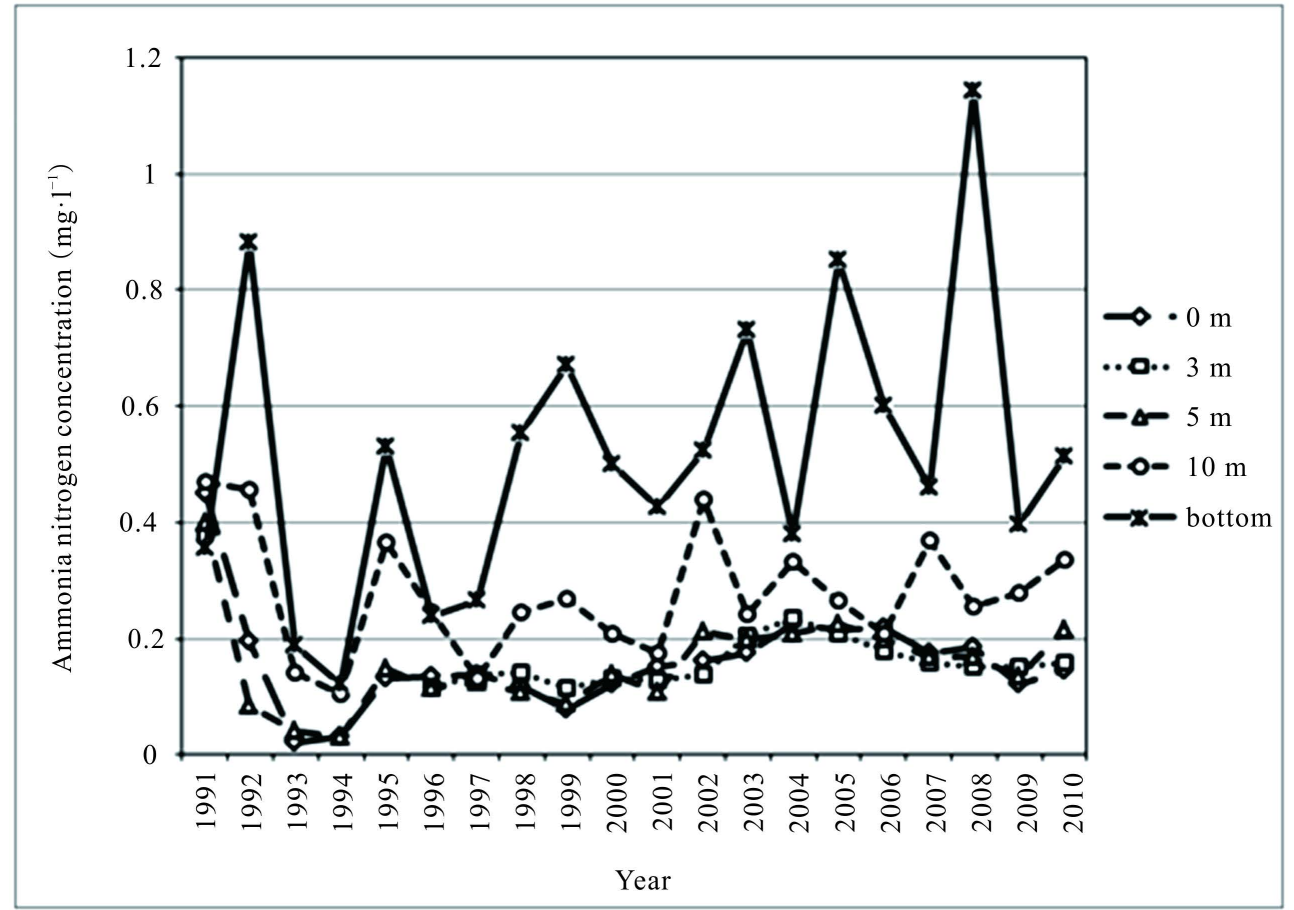

(b)

Figure 5. Average annual values of ammonia nitrogen concentrations in water at (a) Point 1; (b) Point 2. 
Obtained maximum values of TP at the bottom were conditioned by increase in temperature of water at the bottom, which caused the elution of phosphorus in the water column. Increase in values of TP at point 1, compared to point 2, was followed by low values of oxygen concentrations. So in the year 2001 at point 2, and in the year 2002 and in 2008 at point 1, increases in TP concentrations at the bottom were detected and they were followed by an increase in temperature of water at the bottom. The average temperature values of water had been decreasing by depth, at both sampling places, and lower temperatures at the bottom were registered at point 1 in relation to point 2 , due to greater depth. The highest average temperature of water at the bottom at point 2 was registered in $2001\left(12.6^{\circ} \mathrm{C}\right)$, and at point 1 in 2002 and in 2008, when its value was more than $10^{\circ} \mathrm{C}$. During summer period and at the beginning of autumn, there has been a warming of the surface layers of water, and the bottom of the reservoir remained isolated from the epilimnion. Stratification is especially distinct in the years when flow rate in tributaries intensively decreases, and time of water retention in the reservoir is prolonged, which was registered in 2002, when one of the tributaries (Lenovačka river) dried out during summer months.

The values of Chl-a concentration, parameter which indicates the biomass of phytoplankton, were the highest after formation of the reservoir, which is in compliance to the theory of the reservoir's aging. After the inundation of soil, amount of nutrients ( $\mathrm{P}$ and $\mathrm{N}$ ) in water was high, which along with the absence of zooplankton predation causes the massive development of phytoplankton. In the first years of reservoir's life, the highest average values of Chl-a concentration per vertical profile of both points, to a depth of $5 \mathrm{~m}$ depth (Figure 6(a), Figure 6(b)) were recorded. Since then, until the end of the examined period, a clear trend of decreasing Chl-a in water can be noticed.

The development of a zooplankton community occurred with the reservoir's aging, so the biomass of phytoplankton was getting smaller. This shows that the reservoir in the period from 1990 to 1992 went through its first development phase (phase of filling), which is characterized by an increased trophicity, and high average value of nutrients. In the phase of filling it comes to a releasing of nutrients from flooded soil, which was confirmed by high content of TP in the autumn of $1991\left(2 \mathrm{mg} \cdot \mathrm{L}^{-1}\right)$. In this period, decrease in values of DO concentration was registered at the surface (Figure 3(a)) and at the bottom (Figure 3(b)). The trophic state index of Carlson, calculated on the basis of TP, has higher values, compared to the trophic indexes calculated using concentration of Chl-a and transparency (Figure 7). On the basis of the values of TSI ${ }_{\mathrm{TP}}$, it can be concluded that the reservoir was hypereutrophic in the first two years since its formation (1991-1992), eutropho-hypereutrophic in the period from 1993 to 2001, and highly eutrophic from 2002 to 2010. If a criterium of trophicity concentration of Chl-a is taken and converted to TSI $\mathrm{Chl-a}_{\mathrm{a}}$ index, it can be concluded that the reservoir in the year 1991 was hypereutrophic, then until 2001 it was eutrophic, and in the following years its trophicity was on the limit between mesotrophic and eutrophic status. It is important to point out that in November 2002 average annual value of index TSI SD $_{\text {Was }}$ higher than $\mathrm{TSI}_{\mathrm{TP}}$ and in that time intensive bloom of cyanobacteria species Aphanizomenon flos-aquae was registered and water transparency was only $0.2 \mathrm{~m}$.

On the basis of the obtained values of DO, TP and Chl-a concentration, at the surface and at the bottom, at the water intake (point 1), other development phases in the life of the reservoir can be isolated (see Figure 8).

The second development phase in the life of the reservoir, which lasted from the end of the year 1992 to the end of 1996, was characterized by maximum value of Chl-a concentration, as a consequence of a massive development of phytoplankton. At the beginning of this phase, at the bottom at point 1 , low concentrations of DO were registered, with the exception of slight increase in the year 1994 after which the concentration decreased below $2 \mathrm{mg} \cdot \mathrm{L}^{-1}$, which lasted until the end of the examined period. In the third development phase of the reservoir, which lasted from the 1996 until the half of 1998, there had been a decrease in TP and mild increase in the concentration of DO at the bottom. Increase in the content of TP at the bottom of the water intake, characterized the beginning of the last development phase (fourth) which lasted until the end of the examined period. This phase is characterized by problems regarding the sensor characteristics of quality of drinking water, due to the consumer's complaints. Therefore, there is a need for finding the solution for these problems and their adequate rehabilitation. In this period, low water level in the reservoir was detected, as a consequence of reduced water from tributaries, which led to development of stratification in warm months. Appearance of stratification presents one of the most significant factors which cause the cyanobacteria bloom [28]. The water level in the reservoir during the examined period varied up to few meters, and the lowest values were registered in 2002 (depth: $18.8 \mathrm{~m}$ ) and in 1993 (depth: $19.7 \mathrm{~m}$ ), which is graphically presented on the Figure 9 at point 1.

Consumer's complaints, regarding the products of decomposition of blue-green algae, were confirmed directly by their qualitative analysis. In summer months in 2002, one of the tributaries dried out (Lenovačka river), 


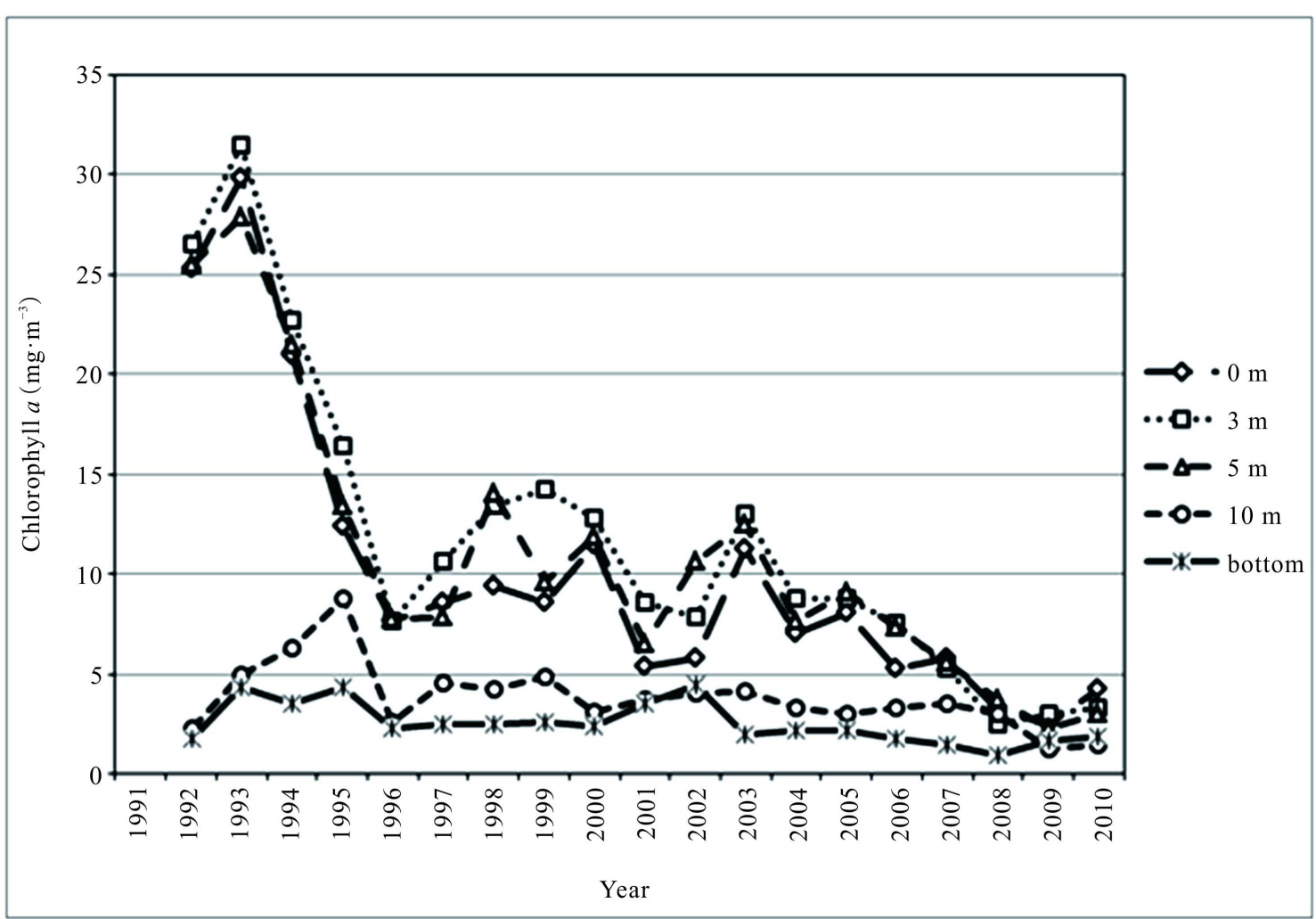

(a)

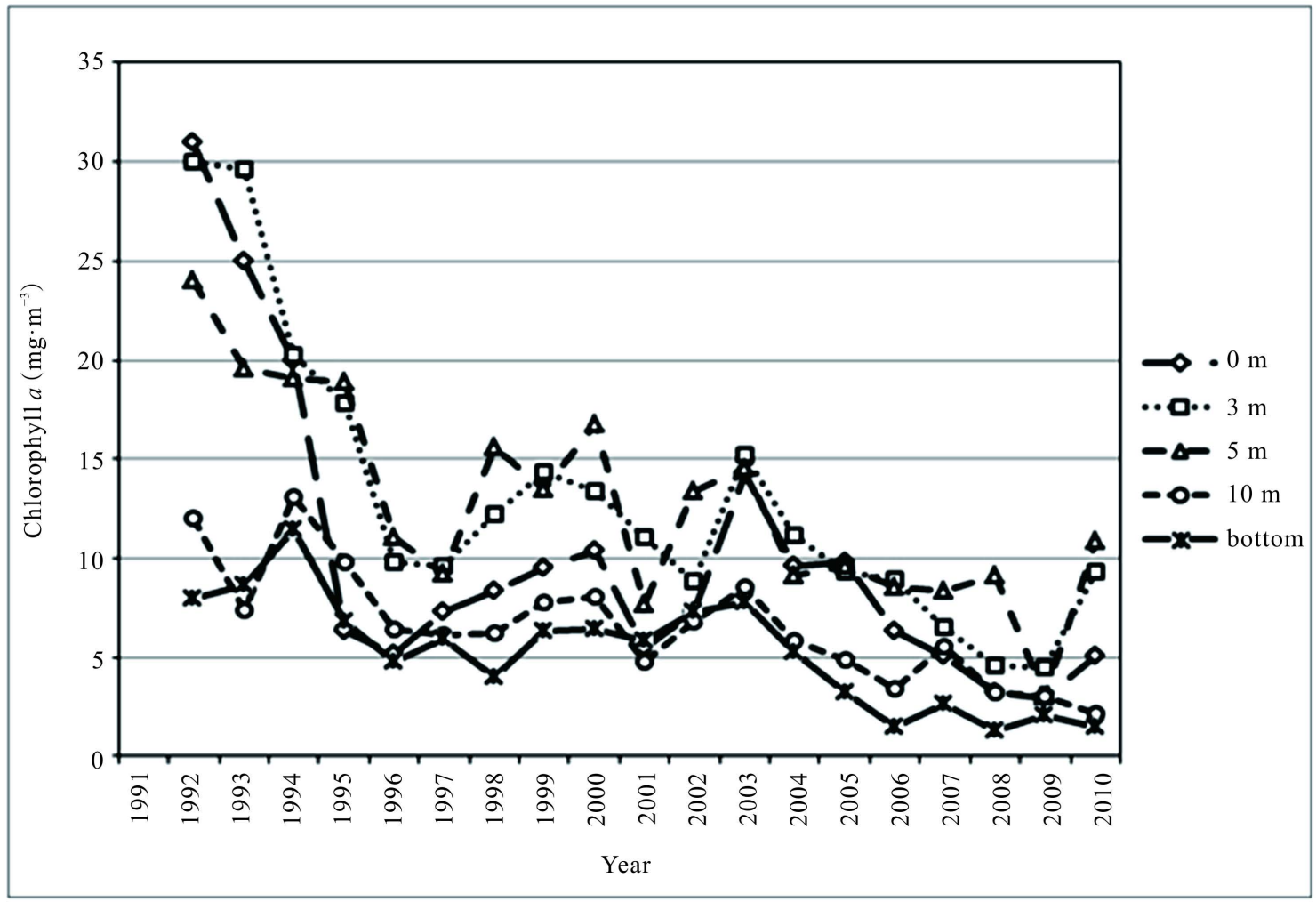

(b)

Figure 6. Average annual values of Chl-a concentrations in water at (a) Point 1; (b) Point 2. 


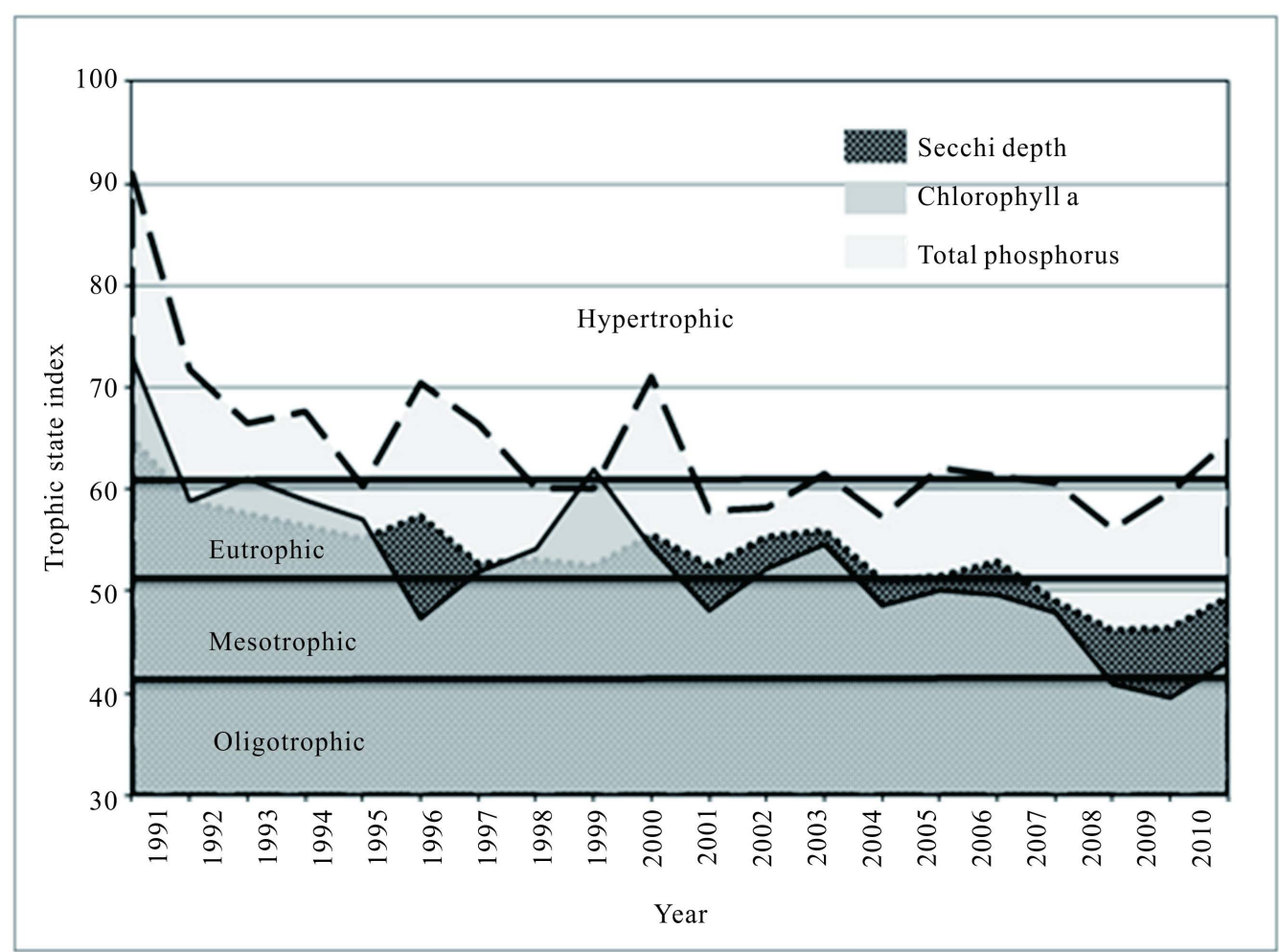

Figure 7. Average values of trophic state indexes TSI ${ }_{S D}, \mathrm{TSI}_{\mathrm{Chl}-\mathrm{a}}$ and $\mathrm{TSI}_{\mathrm{TP}}$.

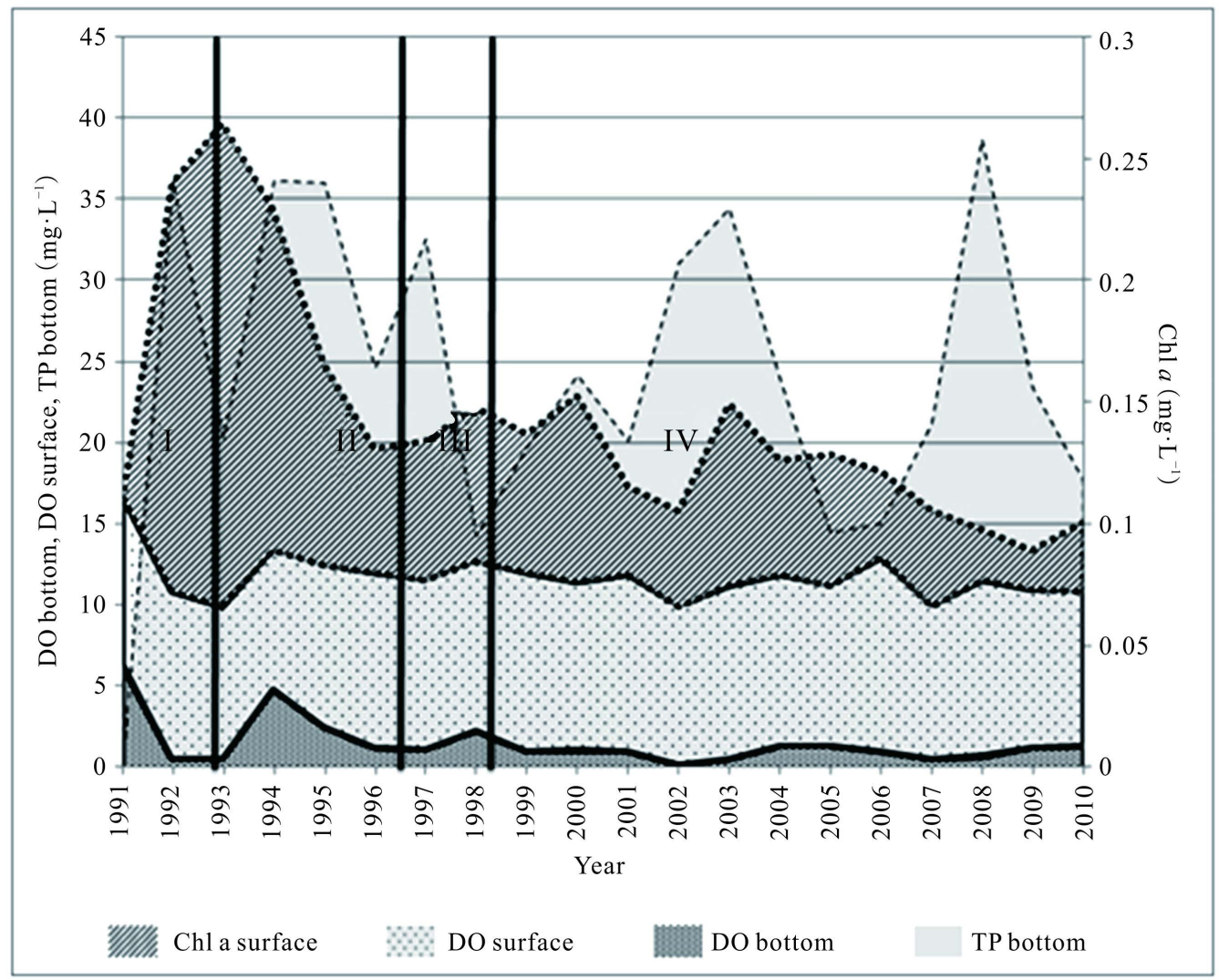

Figure 8. Development phases in the life of Grlište reservoir. 


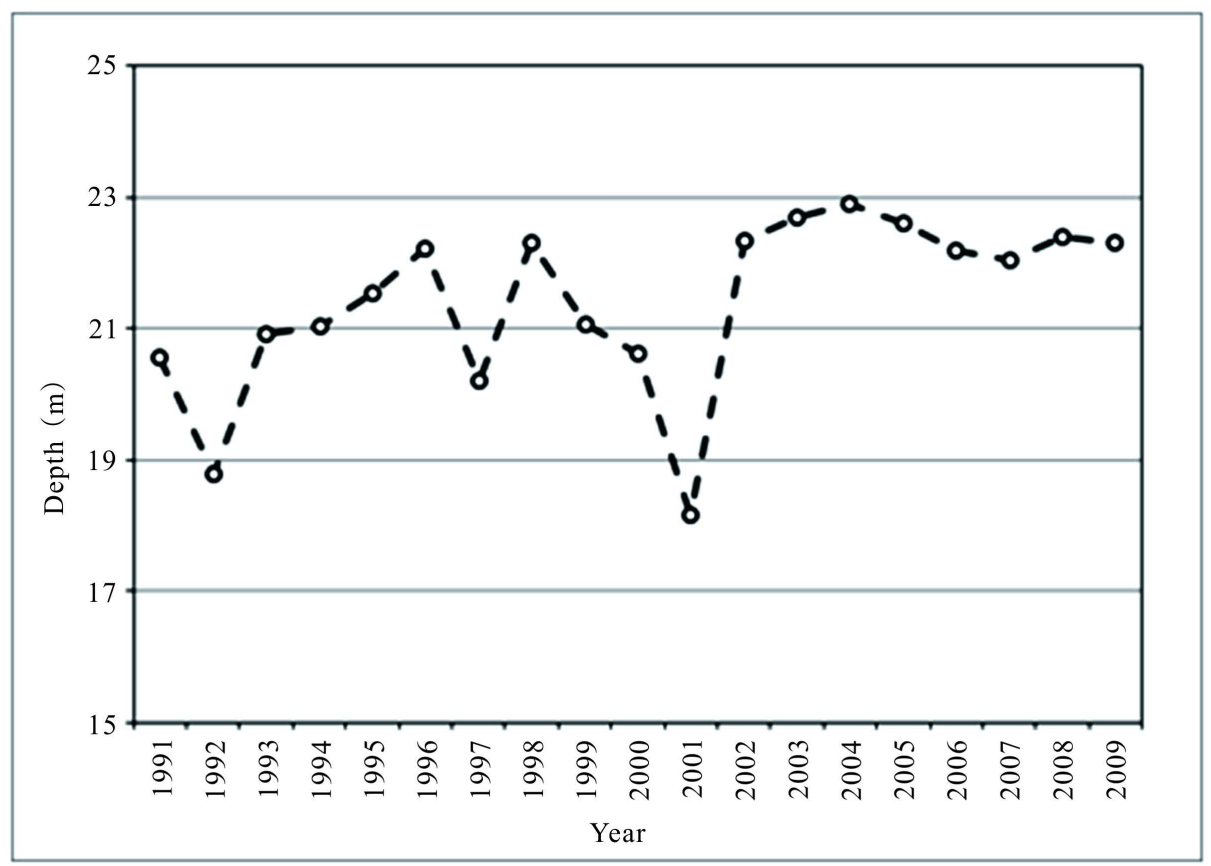

Figure 9. Mean values of water depth in the reservoir at point 1.

which caused lower inflow of water into the reservoir, extended its retention time and created the conditions for a massive occurrence of cyanobacteria with the domination of the species Aphanizomenon flos-aquae [29]. In 2006, the odour of drinking water which reminded on the smell of rot and mold was occurred. Given the fact that occurrence of bloom was not registered in that year, that is most probably the consequence of insufficient knowledge of the cause of degradation of water quality in the reservoir and inadequate frequency of biological monitoring.

In the examined period, the values of trophic status were higher, determined on the basis of TP (TSI $\mathrm{TP}_{\mathrm{TP}}$ ), compared to classification according to biological trophic state index $\left(\mathrm{TSI}_{\mathrm{Chl-a}}\right)$. It is known that the deviation between trophic indexes of Carlson indicates the degree of nutrient limitation [17] [30]. Therefore, the subtraction of indexes $\mathrm{TSI}_{\mathrm{Chl}-\mathrm{a}}-\mathrm{TSI}_{\mathrm{TP}}<0$ indicated that phosphorus was not a limiting factor of algal production, which is confirmed by the absence of correlation between them $(r=0.077, p=0.350, n=149)$. Since it was showed that phosphorus was not a limiting factor of algal production, than the light was probably a limiting factor for the algal growth in the reservoir. On the other hand, a significant correlation between indexes TSI $\mathrm{SD}_{\text {and }} \mathrm{TSI}_{\mathrm{Chl}-\mathrm{a}}(r=$ 0.50, $p<0.001, n=117$ ) was obtained, which indicates that the water transparency of the reservoir Grlište was mostly caused by density of phytoplankton.

\section{Conclusion}

The long-time monitoring of reservoir Grlište has shown that changes of water quality and level of trophicity, above all, are the consequence of synergy effect of negative climate and hydrological regime of the reservoir. Lowering the water level in the reservoir led to the occurrence of summer stratification and suitable conditions for development of cyanobacteria, and thereby to prevent deterioration of drinking water quality, it is necessary for breaking the summer stratification. The most suitable method for this is the application of aeration. On the basis of the obtained concentration of examined nutrients, primarily TP, DO and Chl-a in the water, it was concluded that the reservoir Grlište from its formation, to the end of the examined period, was characterized by four development phases. In the last, the fourth phase, the accumulation was eutrophic, and the cyanobacterial blooming was appeared, representing the indispensable urgent measures of rehabilitation.

\section{Acknowledgements}

This research was supported by the Ministry of Education, Science and Technological Development of the Re- 
public of Serbia, Project OI 176018.

\section{References}

[1] Barinova, S.S. and Nevo, E. (2010) The Upper Jordan River Algal Communities Are Evidence of Long-Term Climatic and Anthropogenic Impacts. Journal of Water Resource and Protection, 2, 507-526. http://dx.doi.org/10.4236/jwarp.2010.26058

[2] Bittencourt-Oliveira, M.C., Moura, A., Hereman, T.C. and Dantas, E.W. (2011) Increase in Straight and Coiled Cylindrospermopsis raciborskii (Cyanobacteria) Populations under Conditions of Thermal De-Stratification in a Shallow Tropical Reservoir. Journal of Water Resource and Protection, 3, 245-252. http://dx.doi.org/10.4236/jwarp.2011.34031

[3] Gecheva, G., Yurukova, L., Cheshmedjiev, S., Varadinova, E. and Belkinova, D. (2013) Integrated Assessment of the Ecological Status of Bulgarian Lowland and Semi-Mountain Natural Lakes. Journal of Environmental Protection, 4, 29-37. http://dx.doi.org/10.4236/jep.2013.46A004

[4] Straškraba, M., Tundisi, J.G. and Duncan, A. (1993) State-of-the-Art of Reservoir Limnology and Water Quality Management. In: Straškraba, M., Tundisi, J.G. and Duncan, A., Eds., Comparative Reservoir Limnology and Water Quality Management, Developments in Hydrobiology, 77, 213-288. http://dx.doi.org/10.1007/978-94-017-1096-1_13

[5] Portielje, R. and Van der Molen, D.T. (1999) Relationship between Eutrophication Variables: From Nutrient Loading to Transparency. Hydrobiologia, 408/409, 375-387. http://dx.doi.org/10.1023/A:1017090931476

[6] Stanković, Ž., Borišev, M., Simić, S., Vučković, M., Igić, R., Vidović, M. and Miljanović, B. (2009) Macrophytes of the Grlište Reservoir (Serbia): Fifteen Years after Its Establishment. Archives of Biological Sciences, 61, 267-278. http://dx.doi.org/10.2298/ABS0902267S

[7] Van Nes, E.H., Winnie, J.R. and Scheffer, M. (2007) A Theory for Cyclic Shifts between Alternative States in Shallow Lakes. Ecosystems, 10, 17-27. http://dx.doi.org/10.1007/s10021-006-0176-0

[8] Jørgensen, S.E., Löffler, H., Rast, W. and Straškraba, M. (2005) Lake and Reservoir Management. Vol. 54, Developments in Water Science, Elsevier Publishers, Amsterdam.

[9] May, L., Spears, B.M., Dudley, B.J. and Hatton-Ellis, T.W. (2010) The Importance of Nitrogen Limitation in the Restoration of Llangorse Lake, Wales, UK. Journal of Environmental Monitoring, 12, 338-346. http://dx.doi.org/10.1039/b912827a

[10] Xu, Y., Cai, Q., Han, X., Shao, M. and Liu, R. (2010) Factors Regulating Trophic Status in a Large Subtropical Reservoir, China. Environmental Monitoring and Assessment, 169, 237-248. http://dx.doi.org/10.1007/s10661-009-1165-5

[11] Nweze, N.O. and Onyishi, U.E. (2011) Phycological Effects of Eutrophication with Fertilizers in Nike Lake, Nigeria. Journal of Water Resource and Protection, 3, 856-860. http://dx.doi.org/10.4236/jwarp.2011.312095

[12] Oliver, R. and Ganf, G. (2000) Freshwater Blooms. In: Whitton, B. and Potts, M., Eds., The Ecology of Cyanobacteria: Their Diversity in Time and Space, Kluwer Academic Publishers, The Netherlands, 149-194.

[13] Burt, T.P., Howden, N.J.K., Worrall, F. and Whelan, M.J. (2010) Long-Term Monitoring of River Water Nitrate: How Much Data Do We Need? Journal of Environmental Monitoring, 12, 71-79. http://dx.doi.org/10.1039/b913003a

[14] Abell, J.M., Hamilton, D.P. and Rutherford, J.C. (2013) Quantifying Temporal and Spatial Variations in Sediment, Nitrogen and Phosphorus Transport in Stream Inflows to a Large Eutrophic Lake. Environmental Science: Processes \& Impacts, 15, 1137-1152. http://dx.doi.org/10.1039/c3em00083d

[15] Böstrom, B., Andersen, J.A., Fleischer, S. and Jansson, M. (1988) Exchange of Phosphorus across the Sediment-Water Interface. Hydrobiologia, 79, 229-244. http://dx.doi.org/10.1007/BF00024907

[16] Beutel, M.W. (2006) Inhibition of Ammonia Release from Anoxic Profundal Sediments in Lakes Using Hypolimnetic Oxygenation. Ecological Engineering, 28, 271-279. http://dx.doi.org/10.1016/j.ecoleng.2006.05.009

[17] Havens, K.E. (1995) Secondary Nitrogen Limitation in a Subtropical Lake Impacted by Non-Point Source Agricultural Pollution. Environmental Pollution, 89, 241-246. http://dx.doi.org/10.1016/0269-7491(94)00076-P

[18] Goldyn, R., Joniak, T., Kowalczewska-Madura, K. and Kozak, A. (2003) Trophic State of Lowland Reservoir during 10 Years after Restoration. Hydrobiologia, 506-509, 759-765. http://dx.doi.org/10.1023/B:HYDR.0000008585.37813.fa

[19] Janjua, M.Y., Ahmad, T. and Akhtar, N. (2009) Limnology and Trophic Status of Shahpur Dam Reservoir, Pakistan. The Journal of Animal \& Plant Sciences, 19, 224-273.

[20] Li, Y.F., Liu, H.Y., Hao, J.F., Zheng, N. and Cao, X. (2012) Trophic States of Creeks and Their Relationship to Changes in Water Level in Xixi National Wetland Park, China. Environmental Monitoring Assessment, 184, 2433 2441. http://dx.doi.org/10.1007/s10661-011-2128-1

[21] Bogdanović, D.M. (2006) The Role of Phosphorus in Eutrophication. Zbornik Matice Srpske za Prirodne Nauke, 110, 
75-86. http://dx.doi.org/10.2298/ZMSPN0611075B

[22] APHA (1999) Standard Methods for the Examination of Water and Wastewater. American Public Health Association, Washington DC.

[23] ASTM (1981) Annual Book of ASTM Standards, D 515-78.

[24] ISO 10260:1992 (1992) Water Quality—Measurement of Biochemical Parameters—Spectrometric Determination of the Chlorophyll—A Concentration. International Organization for Standardization, Geneva.

[25] ASTM (1981) Annual Book of ASTM Standards, D 1426-79.

[26] SRPS ISO 5813:1994 (1994) Water Quality—Determination of Dissolved Oxygen—Iodine Metric Method (Replaced with New SRPS EN 25813:2009).

[27] Carlson, R.E. (1977) A Trophic State Index for Lakes. Limnology and Oceanography, 22, 361-369. http://dx.doi.org/10.4319/lo.1977.22.2.0361

[28] Mitrovic, S.M., Hardwick, L. and Dorani, F. (2011) Use of Flow Management to Mitigate Cyanobacterial Blooms in the Lower Darling River, Australia. Journal of Plankton Research, 33, 229-241. http://dx.doi.org/10.1093/plankt/fbq094

[29] Vučković, M. and Mirjačić-Živković, B. (2002) Fund of Expert Documentation, Belgrade.

[30] Carlson, R.E. (1991) Expanding the Trophic State Concept to Identify Non-Nutrient Limited Lakes and Reservoirs. In: Carpenter, L., Ed., Proceedings of a National Conference on Enhancing the States' Lake Management Programs, North American Lake Management Society, Chicago, 59-71. 
Scientific Research Publishing (SCIRP) is one of the largest Open Access journal publishers. It is currently publishing more than 200 open access, online, peer-reviewed journals covering a wide range of academic disciplines. SCIRP serves the worldwide academic communities and contributes to the progress and application of science with its publication.

Other selected journals from SCIRP are listed as below. Submit your manuscript to us via either submit@scirp.org or Online Submission Portal.
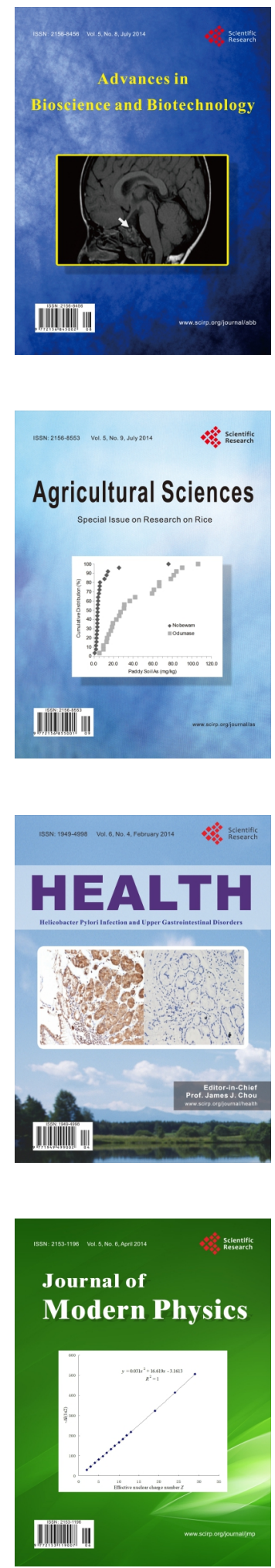
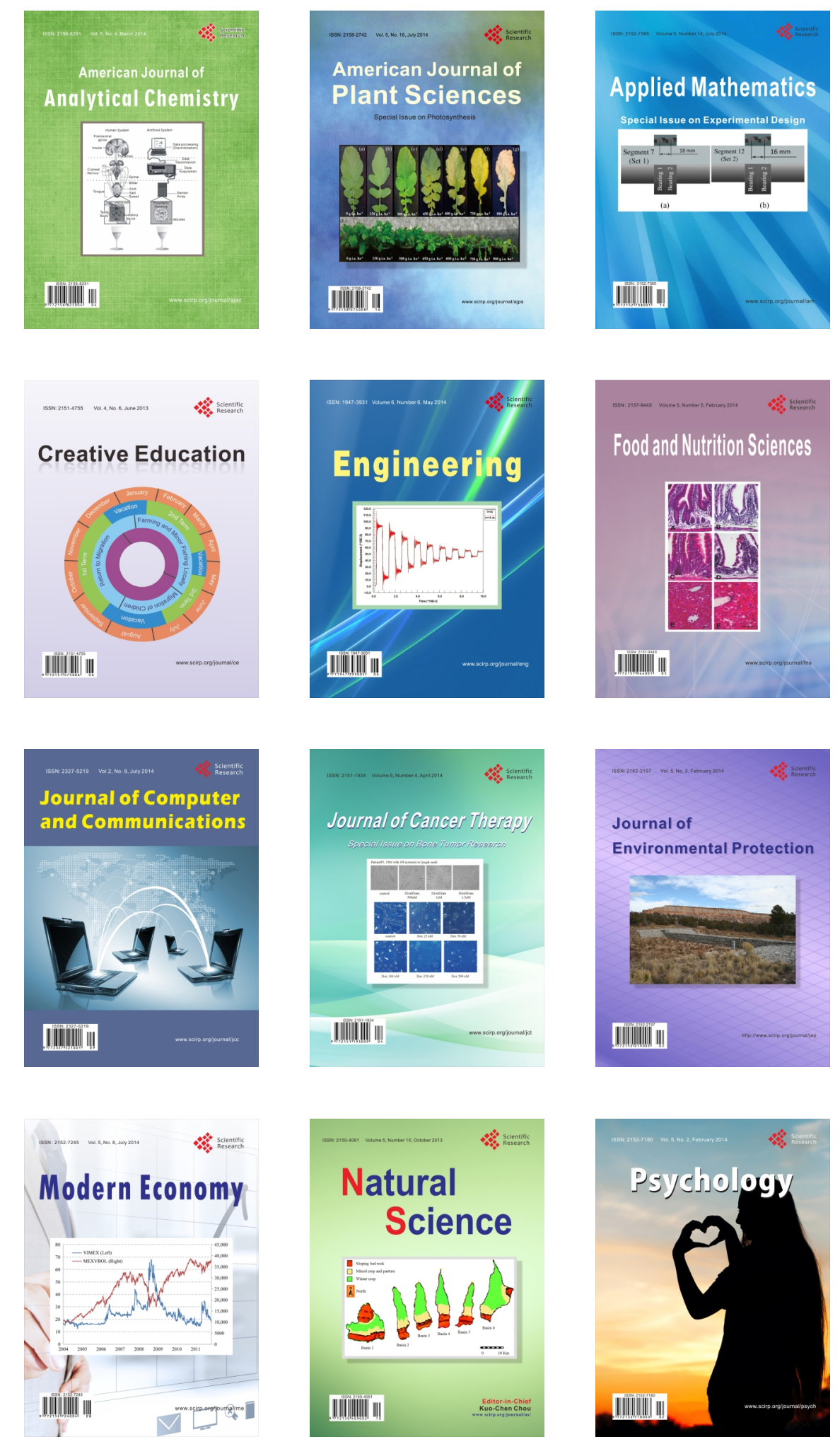